\title{
Performances, lleal and Cecal Microbial Populations and Histological Characteristics in Broilers Fed Diets Supplemented with Lignocellulose ${ }^{[1]}$
}

\author{
Lazar MAKIVIC ${ }^{1} \&$ Milica GLISIC ${ }^{2, a}$ Marija BOSKOVIC ${ }^{2, b}$ Jasna DJORDJEVIC ${ }^{2}$ \\ Radmila MARKOVIC ${ }^{1, c}$ Milan BALTIC ${ }^{2}$ Dragan SEFER ${ }^{1}$
}

\begin{abstract}
${ }^{[1]}$ This paper was supported by the Ministry of Education, Science and Technological Development of the Republic of Serbia via the Project "Selected biological hazards to the safety/quality of food of animal origin and the control measures from farm to consumer" (31034)

1 Department of Nutrition and Botany, Faculty of Veterinary Medicine, University of Belgrade, Bulevar Oslobodjenja 18, 11000 Belgrade, SERBIA

2 Department of Food Hygiene and Technology, Faculty of Veterinary Medicine, University of Belgrade, Bulevar Oslobodjenja 18,11000 Belgrade, SERBIA
\end{abstract}

a ORCID: 0000-0002-6178-1758; ; ORCID: 0000-0002-6178-1758; ' ORCID: 0000-0002-6178-1758

Article ID: KVFD-2018-20356 Received: 14.06.2018 Accepted: 09.10.2018 Published Online: 09.10.2018

How to Cite This Article

Makivic L, Glisic M, Boskovic M, Djordjevic J, Markovic R, Baltic M, Sefer D: Performances, ileal and cecal microbial populations and histological characteristics in broilers fed diets supplemented with lignocellulose. Kafkas Univ Vet Fak Derg, 25 (1): 83-91, 2019. DOI: 10.9775/kvfd.2018.20356

\begin{abstract}
The effect of dietary lignocellulose on broilers performance, intestinal microbiota and morphology, $\mathrm{pH}$ of digesta and litter humidity after 28 and 42 days of the experiment was evaluated. A total of 384 Cobb500 chickens (initial weight: $41.88 \pm 1.56$ g) were divided into 4 groups with 24 replications and fed with control diet (C), a control diet with added $0.4 \%$ of lignocellulose (T1), a diet with added $0.6 \%$ of lignocellulose at the expense of soybean meal and maize (T2), and a diet supplemented with $0.6 \%$ of lignocellulose at the expense of soybean meal (T3). T2 treatment significantly influenced body weight, weight gain (WG), feed intake (FI) and feed conversion ratio (FCR). T2 and T3 treatment increased average LAB and Bifidobacterium spp. count, and decreased the number of Escherichia coli in the ileum and cecum, while differences in cecal Clostridium perfringens count among $0.4 \%$ and $0.6 \%$ treatments were not observed. Feeding the lignocellulose diet did not affect the relative weights of empty proventriculus, gizzard or intestines, but led to a decrease in pHs. T3 treatment caused an increase of the villi heights and significantly lower moisture content in the litter. Even though the addition of lignocellulose into broilers diet positively influenced performances, changes in intestinal microbiota and villi heights, based on the results of the present study, supplementation with $0.6 \%$ lignocellulose is recommended.
\end{abstract}

Keywords: Bifidobacterium spp., Broilers, Intestinal histomorphology, Lignocellulose, Production results

\section{Lignoselüloz İlaveli Diyetle Beslenen Etlik Piliçlerde Performans, İleal ve Sekal Mikrobiyal Popülasyon İle Histolojik Özellikler}

Öz

Diyetteki lignoselülozun 28 ve 42 gün uygulama sonrası broiler tavuklarda performans, barsak mikrobiyatı, morfolojisi ve içerik pH'sı ile

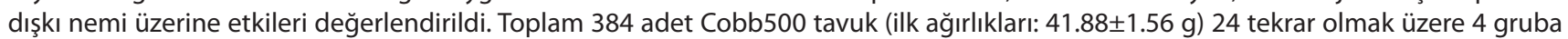
ayrıldı ve kontrol diyet (C), \%0.4 lignoselüloz ilaveli kontrol diyet (T1), soya fasulyesi ve mısır yerine \%0.6 lignoselüloz ilaveli diyet (T2), soyafasulyesi yerine \%0.6 lignoselüloz ilaveli diyet (T3) ile beslendi. T2 uygulaması vücut ağırlığı, ağırık kazanımı, yem tüketimi ve yem konversiyon oranını anlamlı derecede etkiledi. T2 ve T3 uygulamaları ileum ve sekumda ortalama LAB ve Bifidobacterium spp. sayısını artıırken Escherichia coli sayısında azalmaya neden oldu. \%0.4 ile \%0.6 uygulamaları arasında sekum Clostridium perfringens miktarında ise fark belirlenmedi. Lignoselüloz ilaveli diyetle besleme proventrikulus, taşlık ve barsakların orantısal organ ağırıklarını etkilemezken pH'da azalmaya neden oldu. T3 uygulaması, villus uzunluklarında artmaya ve anlamlı derecede dışkının neminde azalmaya neden oldu. Broiler diyetine lignoselüloz ilavesi performans, barsak mikrobiyatası ve villus uzunluğunda pozitif etkilere neden olmuştur. Elde edilen sonuçlar doğrultusunda \% 0.6 oranında lignoselüloz kullanılması önerilmektedir.

Anahtar sözcükler: Bifidobacterium spp., Broiler, Barsak histomorfolojisi, Lignoselüloz, Üretim sonuçları

\section{İletişim (Correspondence) \\ +38765 448413 \\ makivic.lazar@farmofit.ba}




\section{INTRODUCTION}

Addition of dietary fiber to poultry diets could be beneficial in enhancing gut health, which consequently affects broilers performances and meat quality. Soluble dietary fiber contains anti-nutritional factors which can limit digestion and absorption of major nutrients ${ }^{[1-3]}$, leading to bad animal growth performances ${ }^{[4]}$.

Cellulose and lignin are the main components of plant cell walls, $40-50 \%$ and $20-30 \%$, respectively, and therefore, are some of the most widely available organic materials in nature ${ }^{[5]}$. According to previous reports, these nonfermentable fibers are considered to have effects on the energy balance of broilers ${ }^{[6-8]}$. Bogusławska-Tryk et al. ${ }^{[8]}$ showed that different concentrations of lignocellulose in broiler diet promoted the growth of Lactobacillus spp. and Bifidobacterium spp. and reduced the number of Escherichia coli and Clostridium spp. Furthermore, Farran et al. ${ }^{[9]}$ reported that dietary lignocellulose affects litter quality, and that inclusion of $0.8 \%$ lignocellulose in broiler diet significantly improved ready-to-cook carcass yield, lowered abdominal fat pad and increased protein digestibility compared to the control.

To the best of our knowledge, only a few studies reported the effect of including lignocellulose in broiler diets, so there is still a lack of information about effects of this compound on broiler performance and intestinal characteristics, especially intestinal microbiology during the first stages of production. Therefore, the aim of the present study was to evaluate the effects of dietary lignocellulose and basal diet modification in terms of maize and soybean meal content on broiler performance over 42 days, and the $\mathrm{pH}$ of digesta, litter humidity, lactic acid bacteria (LAB), Bifidobacterium spp., Clostridium perfringens and E.coli in intestinal contents and morphological and histological intestinal characteristics in 28-day-old broilers.

\section{MATERIAL and METHODS}

The experimental protocol was approved by the Veterinary Directorate of the Serbian Ministry of Agriculture, Forestry and Water Management (Approval No. 01-990/2) and the Ethics Committee of the Faculty of Veterinary Medicine, University of Belgrade.

\section{Birds, Housing and Feeding}

A total of 384 one-day-old Cobb500 chickens of mixed sexes were divided into control and 3 treatment groups with 6 replicates per group, each of which consisted of 16 chickens. Birds were reared on a commercial poultry farm, following guidelines set by the Cobb Broiler Management Guide ${ }^{[10]}$ from 1 to 42 days of age. The chickens were housed in floor pens and provided with continuous light (24 hours per day) in an environmentally controlled room according to the technological recommendations for the breed. Houses had chopped straw as litter material, approximately $4 \mathrm{~cm}$ thick. Feed and water were offered ad libitum throughout the experiment.

The feeding program was applied as fallow: starter (up to 13 days; crushed pellets), grower (14-28 days; pellets $3.5 \mathrm{~cm}$ ) and finisher (29-42 days; pellets $3.5 \mathrm{~cm}$ ) mixtures. Four experimental diets were used (Table 1): a control without additives $(\mathrm{C})$, diet $\mathrm{T} 1$ consisting of the control diet plus added $0.4 \%$ of a commercial lignocellulose preparation which contains about 70\% acid detergent fiber (ADF) and 24\% acid detergent lignin (ADL) (Arbocel ${ }^{\circledR} \mathrm{R}, \mathrm{J}$. Rettenmaier \& Söhne $\mathrm{GmbH}+\mathrm{CO}$. KG, Rosenberg, Germany); diet T2 with added $0.6 \%$ Arbocel $^{\circledR} \mathrm{R}$ at the expense of $0.3 \%$ soybean meal and $0.3 \%$ maize, and; diet T3 with $0.6 \%$ Arbocel ${ }^{\circledR} \mathrm{R}$ at the expense of $0.6 \%$ soybean meal. The lignocellulose supplementation was only in starter and grower mixtures for the treatment groups (up to day 28), while finisher diets did not differ between groups. Experiment with differences in protein content in the basal diet between groups was designed in order to evaluate if the addition of lignocellulose in different concentrations can replace the reduction of maize and/or soybean meal. The proximate composition of all feed mixtures was analyzed according to AOAC procedures ${ }^{[11]}$ (Table 1).

On day 28 of the trial, after body weight measurements, 12 birds ( 2 birds per pen) from each group were electrically stunned and immediately killed by severance of the jugular veins.

\section{Performance of Broilers}

The body weight of broilers was measured on electronic scales at the start and after every week of fattening. The quantity of feed eaten was recorded on a pen basis and the feed conversion ratio (FCR) was calculated from the data obtained for feed intake and weight gain. The amount of feed wastage and body weight of broilers that died during the study were taken into account when determining the feed conversion ratio.

\section{pH Analysis}

The pHs of fresh gizzard and jejunal digesta were measured using a hand-held pH-meter Testo 205 (Testo $A G$, Lenzkirch, Germany).

\section{Microbiological Analyses}

Contents from the ileum and cecum were collected by squeezing the intestine gently, after which samples were transported in sterile beakers under cold conditions to the laboratory and analyzed for LAB, Bifidobacterium spp., Cl. perfringens and E. coli. The samples were diluted with Ringer's solution, and homogenized for $3 \mathrm{~min}$. Then digesta homogenate was serially diluted to $10^{-9}$ and 0.1 or $1 \mathrm{~mL}$ of appropriately diluted suspension was inoculated directly on the surface of the plates with 
MAKIVIC, GLISIC, BOSKOVIC DJORDJEVIC, MARKOVIC, BALTIC, SEFER

\begin{tabular}{|c|c|c|c|c|c|c|c|c|c|}
\hline \multirow{2}{*}{ Ingredients (\%) } & \multicolumn{4}{|c|}{ Starter (up to 13 days) } & \multicolumn{4}{|c|}{ Grower (days 14-28) } & \multirow{2}{*}{$\begin{array}{c}\text { Finisher* } \\
\text { (days 29-42) }\end{array}$} \\
\hline & C & T1 & T2 & T3 & C & T1 & T2 & T3 & \\
\hline Maize & 40.6 & 40.6 & 40.3 & 40.6 & 45.99 & 45.99 & 45.69 & 45.99 & 44.66 \\
\hline Soybean meal (44\% CP) & 31.1 & 31.1 & 30.8 & 30.5 & 21.86 & 21.86 & 21.56 & 21.26 & 17.75 \\
\hline Soy grits & 7 & 7 & 7 & 7 & 12 & 12 & 12 & 12 & 12 \\
\hline Wheat & 15 & 15 & 15 & 15 & 15 & 15 & 15 & 15 & 20 \\
\hline Soybean oil & 1.71 & 1.71 & 1.71 & 1.71 & 0.78 & 0.78 & 0.78 & 0.78 & 1.68 \\
\hline Chalk & 1.44 & 1.44 & 1.44 & 1.44 & 1.26 & 1.26 & 1.26 & 1.26 & 1.24 \\
\hline Monocalcium phosphate & 1.02 & 1.02 & 1.02 & 1.02 & 0.86 & 0.86 & 0.86 & 0.86 & 0.66 \\
\hline Salt & 0.2 & 0.2 & 0.2 & 0.2 & 0.19 & 0.19 & 0.19 & 0.19 & 0.19 \\
\hline Sodium bicarbonate & 0.17 & 0.17 & 0.17 & 0.17 & 0.15 & 0.15 & 0.15 & 0.15 & 0.17 \\
\hline Lysine & 0.13 & 0.13 & 0.13 & 0.13 & 0.16 & 0.16 & 0.16 & 0.16 & 0.14 \\
\hline Methionine (liquid) & 0.33 & 0.33 & 0.33 & 0.33 & 0.27 & 0.27 & 0.27 & 0.27 & 0.22 \\
\hline Threonine & 0.02 & 0.02 & 0.02 & 0.02 & 0.04 & 0.04 & 0.04 & 0.04 & 0.02 \\
\hline Adsorbent & 0.1 & 0.1 & 0.1 & 0.1 & 0.1 & 0.1 & 0.1 & 0.1 & - \\
\hline Choline chloride & 0.1 & 0.1 & 0.1 & 0.1 & 0.08 & 0.08 & 0.08 & 0.08 & 0.07 \\
\hline Coccidiostat & 0.07 & 0.07 & 0.07 & 0.07 & 0.07 & 0.07 & 0.07 & 0.07 & - \\
\hline Lignin sulfonate & - & - & - & - & 0.2 & 0.2 & 0.2 & 0.2 & 0.2 \\
\hline Premix $^{* *}$ & 1 & 1 & 1 & 1 & 1 & 1 & 1 & 1 & 1 \\
\hline Arbocel $^{\circledR} \mathrm{R}$ & - & 0.4 & 0.6 & 0.6 & - & 0.4 & 0.6 & 0.6 & - \\
\hline \multicolumn{10}{|l|}{ Chemical Composition (\%) } \\
\hline Moisture & 10.47 & 10.51 & 10.58 & 10.42 & 10.78 & 10.75 & 10.80 & 10.46 & 10.91 \\
\hline Total ash & 5.85 & 5.88 & 5.97 & 5.91 & 5.65 & 5.74 & 5.80 & 5.69 & 5.12 \\
\hline Crude protein & 22.07 & 21.92 & 21.74 & 21.79 & 20.81 & 20.77 & 20.42 & 20.08 & 18.46 \\
\hline Crude fiber & 3.43 & 3.79 & 3.98 & 3.96 & 3.25 & 3.67 & 3.85 & 3.82 & 3.07 \\
\hline Total lipids & 5.42 & 5.23 & 5.19 & 5.18 & 5.54 & 5.32 & 5.29 & 5.22 & 6.38 \\
\hline Calcium & 1.01 & 0.99 & 0.98 & 0.99 & 0.91 & 0.90 & 0.89 & 0.88 & 0.82 \\
\hline Phosphorus & 0.65 & 0.64 & 0.66 & 0.66 & 0.58 & 0.59 & 0.60 & 0.60 & 0.57 \\
\hline $\mathrm{NFE}^{* * *}$ & 52.76 & 52.67 & 52.54 & 52.74 & 53.97 & 53.75 & 53.84 & 54.73 & 56.06 \\
\hline \multicolumn{10}{|c|}{ 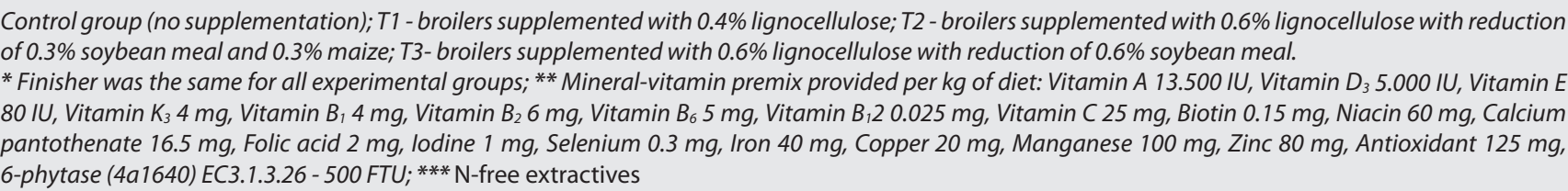 } \\
\hline
\end{tabular}

agar for enumeration of the different bacteria. LAB were enumerated on MRS agar (Hi Media, India) following incubation at $30^{\circ} \mathrm{C}$ for $72 \mathrm{~h}$, E. coli on TBX agar (Oxoid, UK) and plates were incubated for $24 \mathrm{~h}$ at $37^{\circ} \mathrm{C}$. Cl. perfringens were enumerated on Perfringens Agar Base plus supplements TSC and SFP (Oxoid, UK), and plates were incubated for 72 $\mathrm{h}$ at $35^{\circ} \mathrm{C}$, under anaerobic conditions. For enumeration of Bifidobacterium spp., Bifidobacterium Selective Count Agar Base plus Bifido Selective Supplement A and B (Hi Media, India) were used, and plates were incubated for 72 $\mathrm{h}$ at $35^{\circ} \mathrm{C}$ under anaerobic conditions. Bacterial colonies were counted immediately after removing plates from the incubator and the bacterial numbers were expressed as $\log _{10}$ CFU per gram of digesta.

\section{Morphological and Histological Analyses}

After being emptied, proventriculus, gizzard and intestines were weighed on a balance with a precision of $\pm 0.2 \mathrm{~g}$. The intestine samples ( $1 \mathrm{~cm}$ segments) were taken immediately after slaughter, washed in physiological saline and fixed in $10 \%$ buffered formalin. After fixation and shaping, intestinal samples were dehydrated in increasing concentrations of ethyl alcohol, cleared with xylene, paraffin infiltrated and embedded in paraffin blocks. Sections of $2 \mu \mathrm{m}$ in thickness were placed on glass slides and stained with Mayer's hematoxylin and eosin, and with a combination of Periodic acid Schiff's stain and Alcian blue (PAS-AB) ${ }^{[12,13]}$. Histological sections were examined using a light microscope Olympus 
BX53 with the objective magnifications $x 4$ and $x 10$. Morphometric examinations were carried out using the Olympus cellSens software (www.olympus-lifescience. com), and included the following measurements: the villus height and width, and crypt depth of the small intestine (duodenum, jejunum and ileum) ${ }^{[14]}$.

\section{Litter Sample Measurements}

On day 28 of the study, five samples from the full depth of the litter were collected from each pen (4 near the corners and one from the middle). The litter samples for each group were pooled, thoroughly mixed and the moisture content was determined in duplicate by drying at $103 \pm 2^{\circ} \mathrm{C}$ until a constant weight ${ }^{[15]}$.

\section{Statistical Analyses}

Obtained data were statistically processed in GraphPad Prism version 6.00 for Windows (GraphPad Software, San Diego, CA, USA, www.graphpad.com). Results are presented in tables and figure as means and standard error of means (SEM). The significance of differences among the mean values was identified by One-way ANOVA with Tukey's post hoc test. Statistical significance was considered at a level of $\mathrm{P}<0.05$.

\section{RESULTS}

The mortality rate was low (1.0\%), with deaths only in the first week, and not related to any of the treatments. The performances of broilers are shown in Table 2. At the end of week 3 of the trial, the body weight of T2 group differed significantly from the control and T1 group. Subsequently, on days 28 and 42 of the study, T2 broilers had greater body weight compared to birds on other diets $(P<0.05)$.

In weeks 2 to $4,0.6 \%$ lignocellulose supplementation in T2 broilers resulted in their increased weekly weight gain compared to other groups of broilers $(P<0.05)$.

In week 4 of the study, feed intakes of the groups fed with $0.6 \%$ lignocellulose were significantly higher than those of $C$ and $\mathrm{T} 1$ groups of broilers, while in the last two weeks of the study, during which lignocellulose was not added to the feed mixture, feed consumption of all treatment groups was lower than that of the control.

When broilers were fed with grower mixture (week 3), the feed conversion in T2 group was significantly lower than in the control and T3 group, and in the last phase, all groups that had received lignocellulose in feed had a better FCR than did the control $(\mathrm{P}<0.05)$.

\begin{tabular}{|c|c|c|c|c|c|c|c|}
\hline \multirow{2}{*}{ Parameter } & \multirow{2}{*}{ Day } & \multicolumn{4}{|c|}{ Group Mean } & \multirow{2}{*}{ SEM } & \multirow{2}{*}{ P Value } \\
\hline & & C & T1 & T2 & T3 & & \\
\hline \multirow{6}{*}{$\begin{array}{l}\text { Body weight } \\
\text { (g) }\end{array}$} & Day 1 & 41.72 & 42.16 & 41.71 & 41.93 & 0.27 & 0.1516 \\
\hline & Day 7 & $163.00^{\mathrm{a}^{*}}$ & $170.00^{\mathrm{bc}}$ & $174.00^{\mathrm{b}}$ & $167.80^{\mathrm{ac}}$ & 2.56 & $<0.0001$ \\
\hline & Day 14 & 376.30 & 380.10 & 394.60 & 383.10 & 10.14 & 0.1453 \\
\hline & Day 21 & $772.10^{a}$ & $782.10^{\mathrm{a}}$ & $826.20^{b}$ & $785.90^{\mathrm{ab}}$ & 19.39 & 0.0040 \\
\hline & Day 28 & $1191^{a}$ & $1218^{a}$ & $1343^{b}$ & $1253^{a}$ & 30.04 & $<0.0001$ \\
\hline & Day 42 & $2428^{a}$ & $2423^{a}$ & $2611^{b}$ & $2495^{a}$ & 53.87 & $<0.0001$ \\
\hline \multirow{5}{*}{$\begin{array}{l}\text { Weekly weight } \\
\text { gain }(\mathrm{g})\end{array}$} & Day 1-7 & $121.30^{\mathrm{a}}$ & $127.90^{\mathrm{bc}}$ & $132.20^{b}$ & $125.90^{\mathrm{ac}}$ & 2.52 & $<0.0001$ \\
\hline & Day 7-14 & 213.30 & 210.10 & 220.60 & 215.30 & 7.63 & 0.3925 \\
\hline & Day $14-21$ & $395.70^{a}$ & $401.90^{\mathrm{a}}$ & $431.60^{b}$ & $402.80^{\mathrm{a}}$ & 9.46 & $<0.0001$ \\
\hline & Day $21-28$ & $418.90^{\mathrm{a}}$ & $435.40^{\mathrm{a}}$ & $516.50^{b}$ & $467.20^{c}$ & 11.10 & $<0.0001$ \\
\hline & Day $28-42$ & 1284 & 1245 & 1310 & 1292 & 30.96 & $<0.0711$ \\
\hline \multirow{5}{*}{$\begin{array}{l}\text { Weekly feed } \\
\text { intake }(g)\end{array}$} & Day 1-7 & $129.10^{a}$ & $131.90^{\mathrm{a}}$ & $139.60^{\mathrm{b}}$ & $129.90^{\mathrm{a}}$ & 2.11 & $<0.0001$ \\
\hline & Day 7-14 & 302.60 & 292.80 & 302.30 & 297.80 & 14.43 & 0.7473 \\
\hline & Day $14-21$ & 590.10 & 587.80 & 621.40 & 593.50 & 17.71 & 0.0487 \\
\hline & Day 21-28 & $668.60^{a}$ & $674.20^{\mathrm{a}}$ & $786.70^{b}$ & $737.30^{c}$ & 12.24 & $<0.0001$ \\
\hline & Day 28-42 & $2295^{a}$ & $2084^{b}$ & $2186^{c}$ & $2182^{\mathrm{bc}}$ & 87.71 & $<0.0001$ \\
\hline \multirow{5}{*}{$\begin{array}{l}\text { Weekly feed } \\
\text { conversion ratio }\end{array}$} & Day 1-7 & $1.07^{\mathrm{a}}$ & $1.03^{b}$ & $1.06^{a}$ & $1.03^{b}$ & 0.011 & $<0.0001$ \\
\hline & Day 7-14 & 1.42 & 1.39 & 1.37 & 1.38 & 0.067 & 0.7735 \\
\hline & Day $14-21$ & 1.49 & 1.46 & 1.44 & 1.47 & 0.043 & 0.4221 \\
\hline & Day 21-28 & $1.60^{\mathrm{a}}$ & $1.53^{\mathrm{ab}}$ & $1.52^{b}$ & $1.58^{\mathrm{a}}$ & 0.026 & 0.0046 \\
\hline & Day $28-42$ & $1.79^{\mathrm{a}}$ & $1.67^{b}$ & $1.67^{b}$ & $1.69^{b}$ & 0.026 & $<0.0001$ \\
\hline
\end{tabular}


MAKIVIC, GLISIC, BOSKOVIC

DJORDJEVIC, MARKOVIC, BALTIC, SEFER

\begin{tabular}{|c|c|c|c|c|c|c|}
\hline \multirow{2}{*}{ Parameters } & \multicolumn{4}{|c|}{ Group Mean } & \multirow{2}{*}{ SEM } & \multirow{2}{*}{ P Value } \\
\hline & C & T1 & T2 & T3 & & \\
\hline \multicolumn{7}{|l|}{ Weight (\% BW) } \\
\hline Proventriculus & 0.58 & 0.57 & 0.47 & 0.55 & 0.088 & 0.2860 \\
\hline Gizzard & 1.48 & 1.60 & 1.39 & 1.36 & 0.212 & 0.3728 \\
\hline Intestines & 5.33 & 5.16 & 5.84 & 5.47 & 0.603 & 0.4484 \\
\hline \multicolumn{7}{|l|}{$\mathrm{pH}$} \\
\hline Gizzard & $4.311^{a^{*}}$ & $4.20^{b}$ & $4.15^{c}$ & $4.19^{b}$ & 0.016 & $<0.0001$ \\
\hline Jejunum & $4.90^{\mathrm{a}}$ & $4.75^{b}$ & $4.59^{c}$ & $4.69^{d}$ & 0.017 & $<0.0001$ \\
\hline
\end{tabular}

\begin{tabular}{|c|c|c|c|c|c|c|}
\hline \multirow{2}{*}{ Bacterial Group } & \multicolumn{4}{|c|}{ Group Mean } & \multirow{2}{*}{ SEM } & \multirow{2}{*}{ P Value } \\
\hline & C & T1 & T2 & T3 & & \\
\hline \multicolumn{7}{|l|}{$\angle A B$} \\
\hline Ileum & $5.85^{a^{*}}$ & $6.21^{\mathrm{b}}$ & $6.81^{\mathrm{c}}$ & $6.71^{c}$ & 0.178 & $<0.0001$ \\
\hline Cecum & $6.89^{a}$ & $7.21^{\mathrm{b}}$ & $7.52^{c}$ & $7.50^{c}$ & 0.143 & $<0.0001$ \\
\hline \multicolumn{7}{|l|}{ Bifidobacterium } \\
\hline Ileum & $5.61^{\mathrm{a}}$ & $6.32^{b}$ & $6.82^{c}$ & $6.75^{c}$ & 0.174 & $<0.0001$ \\
\hline Cecum & $6.63^{\mathrm{a}}$ & $7.03^{b}$ & $7.38^{\mathrm{c}}$ & $7.31^{\mathrm{bc}}$ & 0.177 & $<0.0001$ \\
\hline \multicolumn{7}{|l|}{ E. coli } \\
\hline Ileum & $6.32^{\mathrm{a}}$ & $5.81^{\mathrm{b}}$ & $5.45^{c}$ & $5.49^{c}$ & 0.106 & $<0.0001$ \\
\hline Cecum & $7.05^{\mathrm{a}}$ & $6.62^{\mathrm{b}}$ & $6.26^{c}$ & $6.30^{c}$ & 0.094 & $<0.0001$ \\
\hline \multicolumn{7}{|l|}{ Cl. perfringens } \\
\hline Ileum & $5.19^{\mathrm{a}}$ & $4.86^{b}$ & $4.59^{\mathrm{bc}}$ & $4.55^{\mathrm{c}}$ & 0.153 & $<0.0001$ \\
\hline Cecum & $5.60^{\mathrm{a}}$ & $5.01^{b}$ & $4.89^{b}$ & $4.81^{b}$ & 0.226 & 0.003 \\
\hline
\end{tabular}

Feeding the lignocellulose diet for four weeks did not result in significant increases in the relative weights of empty proventriculus, gizzard or intestines (Table 3 ).

Significant differences between $\mathrm{pH}$ of gizzard and jejunal digesta were noted between broilers fed different experimental diets. Gizzard and jejunum pHs were lowered by the increased fiber content of the lignocellulose diet. Namely, the inclusion of 0.4 and $0.6 \%$ of lignocellulose led to significant decrease in jejunal $\mathrm{pH}$ of treatment groups ( $\mathrm{pH} 4.75,4.59$ and 4.69, respectively, in T1, T2 and T3 broilers). Also, gizzard pH of treatment groups was significantly lower compared to the control, but without difference between groups $\mathrm{T} 1$ and $\mathrm{T} 3$, and ranged from $\mathrm{pH}$ 4.15 to 4.31 .

The results of average microbial counts in broilers' ileum and cecum are presented in Table 4. The inclusion of lignocellulose in broiler diets significantly affected all bacterial groups in both intestinal segments. The lowest numbers of LAB in the ileum and cecum of broilers were found in the control group $(P<0.05)$. $L A B$ counts were significantly higher $(\mathrm{P}<0.05)$ in the ileum and cecum of broilers fed $0.6 \%$ lignocellulose than in the birds fed $0.4 \%$ lignocellulose, while significant differences between T2 and T3 broilers were not observed.

In the ileal and cecal digesta, the counts of Bifidobacterium spp. were significantly increased $(P<0.05)$, for the broilers fed diets supplemented with $0.4 \%$ and $0.6 \%$ lignocellulose compared to the birds which received the control diet. The highest numbers of Bifidobacterium spp. were measured in the birds fed $0.6 \%$ lignocellulose (T2 group).

The numbers of $E$. coli were significantly lower $(P<0.05)$ in the ileum and cecum of broilers fed lignocellulose than in the control birds, and the lowest average number of this pathogen was recorded in the birds fed $0.6 \%$ lignocellulose.

Clostridium perfringens counts in the ileum were significantly higher $(\mathrm{P}<0.05)$ in the control group than in the broilers fed diets with lignocellulose, while in the cecum, no dose- 


\begin{tabular}{|c|c|c|c|c|c|c|}
\hline \multirow{2}{*}{ Intestinal Segment } & \multicolumn{4}{|c|}{ Group Mean } & \multirow{2}{*}{ SEM } & \multirow{2}{*}{ P Value } \\
\hline & C & T1 & T2 & T3 & & \\
\hline \multicolumn{7}{|l|}{ Duodenum } \\
\hline Villus height & $1330^{\mathrm{a}^{*}}$ & $1380^{\mathrm{a}}$ & $1434^{\mathrm{a}}$ & $1574^{b}$ & 69.38 & $<0.0001$ \\
\hline Villus width & $96.73^{\mathrm{ab}}$ & $105.70^{b}$ & $105.70^{\mathrm{b}}$ & $108.10^{c}$ & 5.61 & 0.0246 \\
\hline Crypt depth & $134.00^{\mathrm{a}}$ & $132.10^{\mathrm{a}}$ & $156.60^{\mathrm{b}}$ & $168.20^{\mathrm{b}}$ & 9.34 & $<0.0001$ \\
\hline \multicolumn{7}{|l|}{ Jejunum } \\
\hline Villus height & $871.40^{\mathrm{a}}$ & $873.40^{\mathrm{ab}}$ & $892.60^{\mathrm{ab}}$ & $984.80^{\mathrm{b}}$ & 61.48 & 0.0301 \\
\hline Villus width & $77.22^{\mathrm{a}}$ & $81.49^{a}$ & $87.64^{\mathrm{a}}$ & $102.10^{\mathrm{b}}$ & 6.24 & $<0.0001$ \\
\hline Crypt depth & $131.90^{\mathrm{a}}$ & $137.00^{\mathrm{ab}}$ & $145.20^{\mathrm{b}}$ & $156.30^{c}$ & 5.53 & $<0.0001$ \\
\hline \multicolumn{7}{|l|}{ Ileum } \\
\hline Villus height & $630.10^{\mathrm{a}}$ & $702.90^{\mathrm{b}}$ & $731.40^{b}$ & $741.20^{\mathrm{b}}$ & 37.34 & 0.0001 \\
\hline Villus width & $70.30^{\mathrm{a}}$ & $82.55^{\mathrm{b}}$ & $88.92^{c}$ & $91.55^{\mathrm{bc}}$ & 4.47 & $<0.0001$ \\
\hline Crypt depth & $131.20^{\mathrm{a}}$ & $140.70^{\mathrm{ab}}$ & $145.60^{b}$ & $145.60^{b}$ & 6.88 & 0.0104 \\
\hline Villus height: Crypt depth ratio & $10.47^{\mathrm{a}}$ & $11.29^{\mathrm{a}}$ & $10.29^{\mathrm{a}}$ & $8.55^{b}$ & 2.62 & $<0.0001$ \\
\hline
\end{tabular}
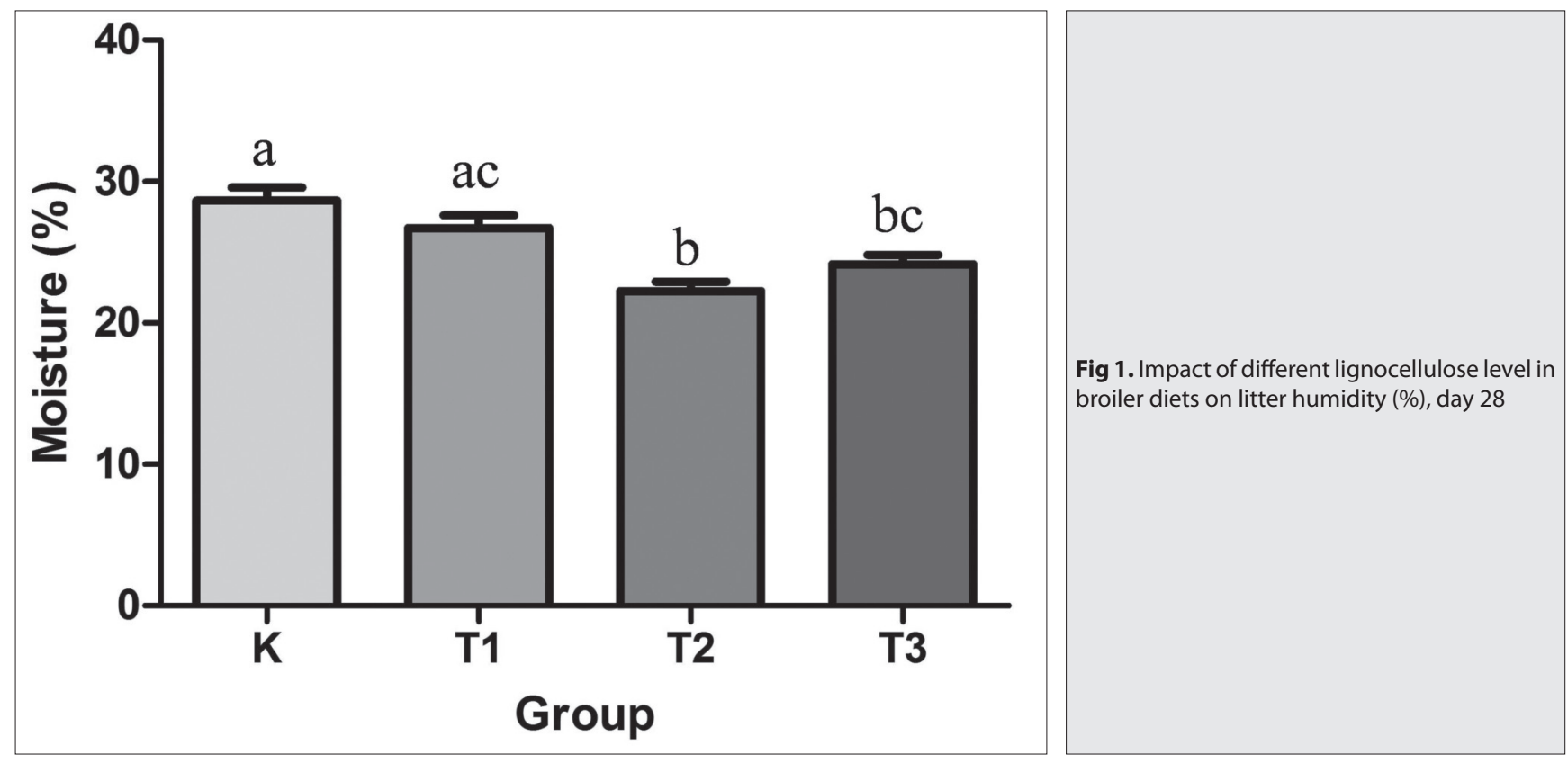

dependent effect of lignocellulose addition was observed. No differences $(P>0.05)$ were found in the mean cecal population of $\mathrm{Cl}$. perfringens among dietary treatments involving addition of $0.4 \%$ or $0.6 \%$ lignocellulose.

Small intestinal morphology of broilers fed experimental diets is shown in Table 5 . Villi of the small intestine segments of the broilers fed $0.6 \%$ lignocellulose (T2 and T3) were higher and wider compare to those broilers fed $0.4 \%$ lignocellulose (T1) and control birds. Crypt depth was also affected with addition of the lignocellulose, with significant increase of crypt depth $(P<0.05)$ in birds with the higher percentage of dietary lignocellulose (T2 and T3) than in the control birds.
The impact of lignocellulose inclusion in broiler diets for four weeks on litter moisture content is presented in Fig. 1. The moisture content in the litter of broilers fed with $0.6 \%$ lignocellulose was significantly lower than in the litter from control birds, with the lowest moisture content (22.25\%) in litter from the T2 broilers.

\section{DISCUSSION}

Many literature data relating to the impact of cellulose and lignin, in the pure form or from the different sources, on production performance and the possibilities of using lignocellulose as a growth promoter in poultry production 
are not consistent ${ }^{[16]}$ which required further investigation that could clarify its effect. In our study, the dietary insoluble fiber affected different production parameters of the experimental birds, where the addition of $0.6 \%$ lignocellulose with the concomitant reduction of $0.3 \%$ soybean meal proved to be the most effective. Previously, Sarikhan et al. ${ }^{[17]}$ determined that supplementation of an insoluble fiber concentrate at the level of $0.25-0.75 \%$ in a broiler diet from weeks 3 to 6 had a positive impact on birds' growth and feed efficiency. Increased digestibility of fats and proteins induced by the addition of insoluble fibers such as lignocellulose could lead to better broilers' growth performance ${ }^{[18,19]}$ which was observed in the present study. Insoluble fiber supplementation can prolong transit time of ingested feed from the crop to the gizzard, and increase gizzard function and proteolytic digestive enzyme activities in the proventriculus and pancreas ${ }^{[4,20-22]}$. In addition, the low $\mathrm{pH}$ in the gizzard of broilers fed with lignocellulose observed in this study could improve the solubility and absorption of mineral salts and favor pepsin activity ${ }^{[23,24]}$. However, some studies showed that inclusion of lignocellulose in diets had no effect on broilers', layers' and roosters' growth performances ${ }^{[4,8,22]}$, or that an excess of dietary fiber reduced feed intake, nutrient digestibility and growth performance ${ }^{[20,25]}$. Thus, a minimum amount of dietary fiber in broilers' diet is required and according to Jiménez-Moreno et al. ${ }^{[20]}$ should be in the range from 2.56 to $3.50 \%$. Our study showed that the addition of $6 \mathrm{~g} / \mathrm{kg}$ lignocellulose preparation with $3.98 \%$ of the crude fiber in the starter, and $3.85 \%$ in the grower feed mixture resulted in the best broiler performances. Namely, there is a limit in reducing the content of the protein part in the feed mixture to which the addition of lignocellulose enables a positive effect on the production results which should not be higher than $0.3 \%$ soybean.

Morphology characteristics of different parts of the digestive tract reported in the study conducted by Kimiaeitalab et $a^{\left[{ }^{[26]}\right.}$ are in agreement with our results. Contrary, JiménezMoreno et al. ${ }^{[20]}$ and Oke and Oke ${ }^{[27]}$ found that the increase of relative weight and length of digestive tract correlate with the higher amount of insoluble fibers in the diet which caused GIT dilation and an increase of the chyme in the gizzard ${ }^{[24]}$.

The inclusion of adequate amounts and types of fiber could modify the $\mathrm{pH}$ of the GIT of broilers ${ }^{[28]}$. The changes in the $\mathrm{pH}$ of the gizzard digesta observed in this study could be the result of stimulated gizzard function and increased production of $\mathrm{HCl}$ in the proventriculus [24], although we did not find any increase of gizzard relative weight. Lower jejunal $\mathrm{pH}$ in our treatment groups could be attributed to bacterial fermentation and consequently higher concentration of short-chain fatty acids ${ }^{[8]}$. Also, Jiménez-Moreno et al. ${ }^{[20]}$ suggested that the crude fiber could stimulate bile salt and bicarbonate secretion, which would result in lowering the $\mathrm{pH}$ of digesta.
Intestinal health and balance between beneficial and pathogenic intestinal bacteria is crucial for maintaining health, leads to better broiler performances, improves feed conversion ratios, and most importantly, reduces the growth of pathogenic bacteria that pose a food safety risk for consumers ${ }^{[29]}$. This is why broilers diets supplemented with different antibiotic replacements (phytobiotics) including the insoluble crude fibers are applied to improve broiler intestinal health.

Despite numerous reports on the influence of pure cellulose and purified lignin when added to broiler diets on the intestinal bacterial population, there are not many data concerning the effect of lignocellulose. In the present study, the addition of lignocellulose in the broiler diets increased the number of beneficial bacteria, $L A B$ and Bifidobacterium spp., and decreased the number of pathogenic bacteria, E. coli and $C l$. perfringens, in ileal and cecal digesta of 28-day-old broilers. These results are in accordance with those previously reported by Bogusławska-Tryk et al. ${ }^{[8]}$ and Abazari et al. ${ }^{[30]}$. Insoluble fibers such as cellulose have an abrasive effect which is exhibited by not allowing pathogenic bacteria to adhere to the intestine mucosal surfaces ${ }^{[8,21]}$. Moreover, lignin contains many phenolic monomers that possess biological effects, including an antibacterial effect. However, in the present study, the lower number of pathogenic bacteria can not be attributed to the antibacterial effect of phenols, since chemical structures from purified lignin differ from native lignin, which is, as in the lignin used in this study, strongly intermeshed with cellulose ${ }^{[31]}$. The number of the $L A B$ was higher in broilers fed diets with lignocellulose, and many $L A B$ are known to release bacteriocins which inhibit or prevent further proliferation of pathogenic

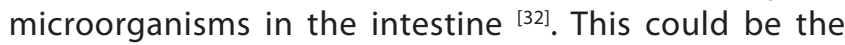
cause of the lower numbers of E. coli and Cl. perfringens we measured in broilers on lignocellulose diets. Lignocellulose supplementation at the $0.6 \%$ level was more effective than the lower level $(0.4 \%)$ supplementation. The effect of lignocellulose on Lactobacillus and Bifidobacterium spp. is dose-dependent as previously reported by Cao et al. ${ }^{[33]}$. However, Bogusławska-Tryk et al. ${ }^{[8]}$ did not find significant differences between the microbiota of broilers fed with $0.25,0.5$ or $1 \%$ lignocellulose.

Diet is one of the main factors influencing birds gut morphology including the villus height: crypt depth ratio which is used as an important indicator of absorption in the small intestine ${ }^{[21]}$. Addition of the lignocellulose caused a major decrease of the crypt depths in the small intestine, and consequently, increase of the villi heights. The higher lignocellulose level had more effect, especially with concomitant reduction of $0.6 \%$ soybean meal. lji et al. ${ }^{[3]}$ reported that jejunal and ileal crypts depths increased in broilers fed a diet with the addition of highly viscous non-starch polysaccharides fibers compared to the control group after 28 days fattening period, while Baurhoo 
et al. $^{[31]}$ found that high protein soybean and cornbased diet containing up to $3 \%$ insoluble fiber exhibit a positive effect on the development of the digestive tract and growth performance of broiler chickens. As previously mentioned, increased beneficial bacterial counts found in the small intestine probably improved vascularization which led to villi development ${ }^{[34]}$ and consequently increased absorption. Furthermore, increased absorption causes greater use of nutrients and digestion capacity explaining better growth performances seen in the groups with lignocellulose supplementation. Similarly, Jiménez- Moreno et al. ${ }^{[20]}$ who investigated the effect of a diet supplemented with pea hulls (2.5-7.5\%) reported that inclusion of lower levels of insoluble fibers improved performances and the villus height:crypt depth ratio, but the addition of $7.5 \%$ pea hulls decreased this ratio.

The poor quality of the litter in poultry production is a serious deficiency that causes various health problems and economic losses ${ }^{[35]}$. Preliminary studies showed that $0.8-1.0 \%$ lignocellulose exhibited a positive impact on a fecal consistency and litter quality in chickens and laying hens ${ }^{[9,16]}$, which was in accordance with T2 and T3 treatment in the present study.

The results from this study show that better broiler production results can be expected if the protein content in broiler diets is reduced, by $0.33 \%$ in starter feed and $0.39 \%$ in grower feed, due to $0.6 \%$ supplementation with lignocellulose, which produces a resultant $0.55 \%$ increase in the crude fiber content of the diet. This implies that the inclusion of lignocellulose can reduce the percent of expensive, high-protein ingredients in the feed mixture in a cost-effective manner. Overall, the presence of $0.4 \%$ and $0.6 \%$ lignocellulose in broiler diets decreased populations of C. perfringens and $E$. coli and increased populations of $L A B$ and Bifidobacterium spp. in both ileal and cecal segments, and a dose-dependent effect was observed. Addition of the lignocellulose in the present study caused a decrease of the crypt depths in all segments of the small intestine, and consequently, increase of the villi heights. The higher lignocellulose level $(0.6 \%)$ had more effect compared to supplementation with the lower concentration of lignocelluloses.

\section{Conflict OF InTEREST}

The authors declare no conflict of interest.

\section{REFERENCES}

1. JøRgensen $H$, Zhao XQ, Knudsen KEB, Eggum BO: The influence of dietary fibre source and level on the development of the gastrointestinal tract, digestibility and energy metabolism in broiler chickens. Br J Nutr, 75 (3): 379-395, 1996. DOI: 10.1079/BJN19960141

2. Smits CH, Veldman A, Verkade HJ, Beynen AC: The inhibitory effect of carboxymethylcellulose with high viscosity on lipid absorption in broiler chickens coincides with reduced bile salt concentration and raised microbial numbers in the small intestine. Poult Sci, 77 (10): 1534-1539, 1998. DOI: $10.1093 / \mathrm{ps} / 77.10 .1534$
3. Iji PA, Saki AA, Tivey DR: Intestinal development and body growth of broiler chicks on diets supplemented with non-starch polysaccharides. Anim Feed Sci Technol, 89 (3-4): 175-188, 2001. DOI: 10.1016/S03778401(00)00223-6

4. Farran MT, Akilian HA, Hamoud AM, Barbour GW, Saoud IP: Lignocellulose improves protein and amino acid digestibility in roosters and egg hatchability in broiler breeders. J Poult Sci, 54 (3): 197-204, 2017. DOI: $10.2141 /$ jpsa.0160095

5. Lamid M, Kusriningrum, Al-Arif A, Warsito SH: Improving the quality of rice bran by utilization of lignocellulosic enzymes for broiler feed. $J$ Appl Environ Biol Sci, 5 (12): 227-230, 2015.

6. Svihus B, Hetland H: lleal starch digestibility in growing broiler chickens fed on a wheat-based diet is improved by mash feeding, dilution with cellulose or whole wheat inclusion. Br Poult Sci, 42 (5): 633-637, 2001. DOI: 10.1080/00071660120088461

7. Krás RV, Kessler AM, Ribeiro AML, Henn J, Dos Santos II, Halfen DP, Bockor L: Effect of dietary fiber and genetic strain on the performance and energy balance of broiler chickens. Rev Bras Cienc Avic, 15 (1): 15-19, 2013. DOI: $10.1590 / S 1516-635 X 2013000100003$

8. Bogusławska-Tryk M, Szymeczko R, Piotrowska A, Burlikowska K, Śliżewska K: Ileal and cecal microbial population and short-chain fatty acid profile in broiler chickens fed diets supplemented with lignocellulose. Pak Vet J, 35 (2): 212-216, 2015.

9. Farran MT, Pietsch $\mathbf{M}$, Chabrillat T: Effect of lignocellulose on the litter quality and the ready to cook carcass yield of male broilers. Actes des 10 èmes Journées de la Recherche Avicole et Palmipèdes à Foie Gras du 26 au 28 mars, 2013, La Rochelle, France, 917-921, 2013.

10. Vantress C: Cobb broiler management guide. Cobb-Vantress, Siloam Springs, AR, USA, 2012

11. Association of Official Analytical Chemists. Official Method of Analysis. $16^{\text {th }}$ ed., AOAC. Washington, DC, 1995.

12. Smirnov A, Perez R, Amit-Romach E, Sklan D, Uni Z: Mucin dynamics and microbial populations in the chicken small intestine are changed by dietary probiotic and antibiotic growth promoter supplements. J Nutr, 135 (2): 187-192, 2005. DOI: 10.1093/jn/135.2.187

13. Yamabayashi S: Periodic acid-Schiff-Alcian Blue: A method for the differential staining of glycoproteins. Histochem J, 19 (10-11): 565-571, 1987. DOI: 10.1007/BF01687364

14. Aptekmann KP, Artoni SMB, Stefanini MA, Orsi MA: Morphometric analysis of the intestine of domestic quails (Coturnix coturnix Japonica) treated with different levels of dietary calcium. Anat Histol Embryol, 30 (5): 277-280, 2001. DOI: 10.1046/j.1439-0264.2001.00331.x

15. ISO 1442:1997. Meat and meat products - Determination of moisture content (Reference method), 1997.

16. Bogusławska-Tryk M, Piotrowska A, Szymeczko R, Burlikowska K, Głowińska B: Lipid metabolism indices and fatty acids profile in the blood serum of broiler chickens fed a diet with lignocellulose. Rev Bras Cienc Avic, 18 (3): 451-456, 2016. DOI: 10.1590/1806-9061-2015-0157

17. Sarikhan M, Shahryar HA, Gholizadeh B, Hosseinzadeh $\mathrm{MH}_{\text {, }}$ Beheshti B, Mahmoodnejad A: Effects of insoluble fiber on growth performance, carcass traits and ileum morphological parameters on broiler chick males. Int J Agric Biol, 12 (4): 531-536, 2010.

18. González-Alvarado JM, Jiménez-Moreno E, González-Sánchez D, Lázaro R, Mateos GG: Effect of inclusion of oat hulls and sugar beet pulp in the diet on productive performance and digestive traits of broilers from 1 to 42 days of age. Anim Feed Sci Technol, 162 (1-2): 37-46, 2010. DOI: 10.1016/j.anifeedsci.2010.08.010

19. Bogusławska-Tryk M, Piotrowska A, Szymeczko R, Burlikowska K: Effect of dietary lignocellulose on ileal and total tract digestibility of fat and fatty acids in broiler chickens. J Anim Physiol Anim Nutr, 100 (6): 10501057, 2016. DOI: 10.1111/jpn.12476

20. Jiménez-Moreno $E$, Chamorro $S$, Frikha M, Safaa HM, Lázaro R, Mateos GG: Effects of increasing levels of pea hulls in the diet on productive performance, development of the gastrointestinal tract, and nutrient retention of broilers from one to eighteen days of age. Anim Feed SciTechnol, 168 (1-2): 100-112, 2011.DOI: 10.1016/j.anifeedsci.2011.03.013 
MAKIVIC, GLISIC, BOSKOVIC

DJORDJEVIC, MARKOVIC, BALTIC, SEFER

21. Mateos GG, Jiménez-Moreno E, Serrano MP, Lázaro RP: Poultry response to high levels of dietary fiber sources varying in physical and chemical characteristics. J Appl Poult Res, 21 (1): 156-174, 2012. DOI: 10.3382/japr.2011-00477

22. Yokhana JS, Parkinson G, Frankel TL: Effect of insoluble fiber supplementation applied at different ages on digestive organ weight and digestive enzymes of layer-strain poultry. Poult Sci, 95 (3): 550-559, 2015 DOI: $10.3382 / \mathrm{ps} /$ pev336

23. Guinotte F, Gautron J, Nys Y, Soumarmon A: Calcium solubilization and retention in the gastrointestinal tract in chicks (Gallus domesticus) as a function of gastric acid secretion inhibition and of calcium carbonate particle size. Br J Nutr, 73 (1): 125-139, 1995. DOI: 10.1079/BJN19950014

24. Jiménez-Moreno $E$, González-Alvarado JM, de Coca-Sinova $A$, Lázaro R, Mateos GG: Effects of source of fibre on the development and $\mathrm{pH}$ of the gastrointestinal tract of broilers. Anim Feed Sci Technol, 154 (1-2): 93-101, 2009. DOI: 10.1016/j.anifeedsci.2009.06.020

25. Sklan D, Smirnov A, Plavnik I: The effect of dietary fibre on the small intestines and apparent digestion in the turkey. Br Poult Sci, 44 (5): 735 740, 2003. DOI: 10.1080/00071660310001643750

26. Kimiaeitalab MV, Goudarzi SM, Jiménez-Moreno E, Cámara L, Mateos GG: A comparative study on the effects of dietary sunflower hulls on growth performance and digestive tract traits of broilers and pullets fed a pullet diet from 0 to 21 days of age. Anim Feed Sci Technol, 236, 57 67, 2018. DOI: 10.1016/j.anifeedsci.2017.11.023

27. Oke DB, Oke MO: Effects of feeding graded levels of sawdust obtained from Daniellia ogea tree on the performance and carcass characteristics of broiler chickens. Res J Poult Sci, 1 (1): 12-15, 2007.

28. Hetland H, Svihus B, Choct M: Role of insoluble fiber on gizzard activity in layers. J Appl Poult Res, 14 (1): 38-46, 2005. DOI: 10.1093/japr/14.1.38

29. Roberts T, Wilson J, Guthrie A, Cookson K, Vancraeynest D, Schaeffer J, Moody R, Clark S: New issues and science in broiler chicken intestinal health: Intestinal microbial composition, shifts, and impacts. Worlds Poult Sci J, 71 (2): 259-270, 2015. DOI: 10.1017/S0043933915000276

30. Abazari A, Navidshad B, Mirzaei Aghjehgheshlagh F, Nikbin S: The effect of rice husk as an insoluble dietary fiber source on intestinal morphology and Lactobacilli and Escherichia coli populations in broilers. Iran J Vet Med, 10 (3): 217-224, 2016. DOI: 10.22059/IJVM.2016.58684

31. Baurhoo B, Ruiz-Feria CA, Zhao X: Purified lignin: Nutritional and health impacts on farm animals-A review. Anim Feed Sci Technol, 144 (3-4) 175-184, 2008. DOI: 10.1016/j.anifeedsci.2007.10.016

32. O'Shea EF, Cotter PD, Stanton C, Ross RP, Hill C: Production of bioactive substances by intestinal bacteria as a basis for explaining probiotic mechanisms: bacteriocins and conjugated linoleic acid. Int J Food Microbiol, 152 (3): 189-205, 2012. DOI: 10.1016/j.ijfoodmicro.2011.05.025

33. Cao BH, Zhang XP, Guo YM, Karasawa Y, Kumao T: Effects of dietary cellulose levels on growth, nitrogen utilization, retention time of diets in digestive tract and cecal microflora of chickens. Asian-Australas J Anim Sci, 16 (6): 863-866, 2003. DOI: 10.5713/ajas.2003.863

34. Stappenbeck TS, Hooper LV, Gordon JI: Developmental regulation of intestinal angiogenesis by indigenous microbes via Paneth cells. Proc Natl Acad Sci U S A, 99 (24): 15451-15455, 2002. DOI: 10.1073/ pnas.202604299

35. Youssef IMI, Beineke A, Rohn K, Kamphues J: Experimental study on effects of litter material and its quality on foot pad dermatitis in growing turkeys. Int J Poult Sci, 9 (12): 1125-1135, 2010. DOI: 10.3923/ ijps.2010.1125.1135 